\title{
TRADUÇÃO E AUTORIA: DE SCHLEIERMACHER A VENUTI
}

\author{
Luana Ferreira de Freitas \\ Universidade Federal de Santa Catarina \\ luanafreitas.luana@gmail.com
}

\begin{abstract}
Resumo: Este artigo é a continuação de uma discussão anterior acerca da autoria como concebida por Lawrence Venuti. O modelo de tradução proposto por Venuti para redefinir o prestígio do tradutor buscando a sua visibilidade foi lançado por Schleiermacher no século XIX. O artigo analisa a concepção de tradução proposta por Schleiermacher e apropriada por Venuti e faz um exame das divergências de fundamentos, metas e contingências que sustentam ambas argumentações de intervenção consciente na prática da tradução.
\end{abstract}

Palavras-chave: tradução, autoria, estratégia, intervenção.

\begin{abstract}
This paper is a continuation of an earlier discussion on authorship as conceived by Lawrence Venuti. The translation model proposed by Venuti to redefine the translator's prestige through visibility was established by Schleiermacher in the 19th century. This paper presents an analysis of the conception of translation Schleiermacher proposed that was appropriated by Venuti and considers discrepancies of bases, goals and circumstances that support both arguments of deliberate intervention in the practice of translation.
\end{abstract}

Keywords: translation, authorship, strategy, intervention.

L'auteur est mythique, qui se reconstruit après coup, transportant l'effet dans la cause; mythe pour luimême, et encore plus pour le lecteur ${ }^{l}$

Desde as traduções do grego ao latim, os debates concernentes à prática tradutória da literatura concentravam-se nos textos, nas 
línguas e nos autores e binarismos do tipo texto de partida/texto de chegada ou conteúdo/forma estabeleceram-se nos discursos dos estudiosos da tradução. Para Cícero, por exemplo, o tradutor deveria atentar para a retórica e a eloqüência: "Instruir é uma obrigação, deleitar, uma honra, comover, indispensável." E, mais adiante, quando comenta uma tradução sua de Ésquines e Demóstenes, ele afirma: "Traduzi (...) com os mesmos pensamentos e suas formas bem como com suas figuras, com palavras adequadas ao nosso costume. Para tanto não tive necessidade de traduzir palavra por palavra, mas mantive o gênero das palavras e sua força."

A mesma preocupação com a produção literária e o efeito estético na língua de chegada observa-se ao longo do Renascimento. Poder-se-ia inferir pois que o tradutor gozava de estatuto de autor, uma vez que ele produzia um texto que primava pelo seu efeito na cultura de chegada e, por conseguinte, poderia interferir mais na escritura do texto produzido. Contudo, Bruni afirma que

na tradução o ótimo tradutor se transforma com toda a mente, alma e determinação no autor do primeiro escrito e assim transformará a forma, postura e textura do discurso, tentando expressar a cor e os diversos matizes. (...) Uma vez que cada escritor tem uma maneira peculiar de escrever, Cícero a prolixidade e abundância, Salústio a austeridade e brevidade, Lívio a grandeza semi-agreste, o bom tradutor deverá se adaptar ao estilo de cada um.

Fica dessa maneira limitada a inserção do tradutor na produção do seu texto ao gênio do autor.

A radicalização dessa subserviência do tradutor em relação ao autor surge com os ideais românticos a partir de o século XIX. A originalidade do autor passa a povoar as discussões literárias, assim com sua intenção e estilo. O texto de partida passa a estabelecer uma relação narcísica com seu autor e passa a ser visto como reflexo de uma visão de mundo própria, única e, por isso mesmo, não passível de reprodução. Com a valorização da autoria, a tradu- 
ção teve seu papel redefinido e questões como a fidelidade e a equivalêcia à intenção e ao estilo do autor tornaram-se balizas para tradutores, leitores e editoras. Mounin comenta o estatuto do tradutor no século XIX:

E il traduttore (a meno che non sia egli stesso uno scrittore stimato nella sua lingua materna) diventa allora il povero traduttore, l'oscuro cottimista mal pagato, sempre negletto, privo di qualsiasi diritto sulla merce che produce quando l'abbia venduta, il cui nome può figurare o no sulla copertina dell'opera, secondo il capriccio dell'editore (o persino della distrazione dell'editore o dello stampatore) e di cui i critici non parlano quasi mai, se non per deriderlo, concedendogli solo una riga e mezzo alla fine della loro cronaca, per un errore di stile o di lingua che hanno scoperto o creduto di scoprire nella sua traduzione (1965, p. 206).

A busca incansável pela fidelidade ao original advogada por teóricos que encaravam a tradução como uma atividade mecânica de reprodução e o tradutor como copista de textos, foi redimensionada. A partir de os anos sessenta, muitos paradigmas foram repensados. Havia a preocupação de incorporar socialmente valores e discursos reprimidos. Foi em meio a esse movimento contestatório que a teoria da tradução passou a repensar o estatuto da tradução e do tradutor. Então dicotomias como autor/tradutor, original/tradução, tradução fiel/tradução livre estabeleceram-se nos discursos acadêmicos e promoveram toda sorte de discussões no que tange ao papel social do tradutor.

As questões e, principalmente, os questionamentos concernentes à autoria e à autoridade do tradutor têm sido motivo de debates acalorados e inconclusivos. O reconhecimento do caráter autoral da atividade tradutória tem ocupado o palco das discussões na teoria da tradução e muitas hipóteses têm sido propostas para estabelecer a identidade do tradutor na sua produção. Lawrence Venuti é um dos estudiosos da tradução que tem se dedicado à questão da 
autoria do tradutor aliada a um posicionamento mais crítico diante dos discursos hegemônicos da cultura de língua inglesa. A invisibilidade do tradutor, defende Venuti, se deve à concepção de autoria na cultura anglo-americana:

According to this conception, the author freely expresses his thoughts and feelings in writing, which is thus viewed as an original and transparent self-representation, unmediated by transindividual determinants (linguistic, cultural, social) that might complicate authorial originality $(1995$, p.6).

Três anos mais tarde, Venuti reafirma a sua posição:

Perhaps the most important factor in the current marginality of translation is its offense against the prevailing concept of authorship. Whereas authorship is generally defined as originality, self-expression in a unique text, translation is derivative, neither self-expression nor unique: it imitates another text. Given the reigning concept of authorship, translation provokes the fear of inauthenticity, distortion, contamination (1998, p. 31).

Venuti, fundamentado pelo marxismo, defende que a interpretação e a manifestação discursiva são condicionadas por fatores alheios ao produtor textual e balizadas pelas conjunturas históricas e ideológicas da cultura na qual o discurso é produzido. Dessa maneira, os significados ativados em um texto por um escritor são construtos determinados política e socialmente e balizados pelas práticas sociais. Nas suas palavras, "[t]he viability of a translation is established by its relationship to the cultural and social conditions under which it is produced and read" (1995, p. 18).

Assim, Venuti revê os ideais românticos acerca da autoria prevalecentes na teoria e prática literárias ao contestar valores como autenticidade, originalidade e estilo próprios. Se a produção literá- 
ria é limitada por um contexto preestabelecido e se o significado é coletivo e construído culturalmente, então conceitos como criatividade e neutralidade autorais inexistem.

Venuti questiona então a superioridade da empresa do autor em detrimento da do tradutor mediante exame das relações de produção consoante a sua visão marxista e lança mão do conceito de consumibilidade, que prevê que quanto maior for o acesso e a legibilidade da tradução, maior será o seu prestígio enquanto mercadoria e menor será a visibilidade do tradutor.

Here it becomes clear that the valorization of transparency conceals the manifold conditions under which a translation is produced and consumed - starting with the translator and the fact of translation. A fluent strategy aims to efface the translator's crucial intervention in the foreign text: he or she actively rewrites it in a different language to circulate in a different culture, but this very process results in a self-annihilation, ultimately contributing to the cultural marginality and economic exploitation which translators suffer today. (...) Moreover, since fluency leads to translations that are eminently readable and therefore consumable on the book market, it assists in their commodification and contributes to the cultural and economic hegemony of target-language publishers (VENUTI, 1992, pp. 4-5).

Partindo desse pressuposto, Venuti sugere como estratégia de tradução a visibilidade do tradutor que se daria por meio da subversão dos modelos discursivos hegemônicos. Os princípios no quais Venuti fundamentou a sua busca pelo reconhecimento autoral do tradutor foram lançados por Friedrich Schleiermacher em 1813.

Schleiermacher acreditava haver duas possibilidades para o tradutor: "Either the translator leaves the author in peace, as much as possible, and moves the reader toward him. Or he leaves the reader in peace, as much as possible, and moves the author toward him." 2 (p. 149). A opção de Schleiermacher é claramente pela primeira e 
o autor via nessa estratégia política o fortalecimento da língua e cultura alemãs:

[c]oincidentally our nation, which respects what is foreign and is destined for mediation by its very nature, may be called upon to carry all the treasures of foreign art and foreign scholarship in its language (...) With the help of our language all nations would then be able to enjoy whatever beauty the most different times have brought forth (...) (p. 165).

Pym e Berman fazem um exame detalhado desse patriotismo veemente de Schleiermacher em oposição à estética francesa vigente:

The lecuture was very much part of a moment in German letters, participating in a general attempt to oppose German Romantic aesthetics to the belles infidèles of French Neoclassicism. If the good method was to be German (literalist, predominantly from Greek), the not-so-good method was unmistakably French (naturalizing, more frequently from Latin) (PYM, 1995).

Berman (1984) trata da suposta abertura ao estrangeiro apregoada por Schleiermacher e do bilingüismo cultural alemão:

Et Schleiermacher montre que ce type de traduction est lié, au moin en Allemagne, à une situation culturelle dans laquelle la langue nationale ne s'est pas encore auto-affirmée, dans laquelle elle ne peut ni accueillir les autres langues dans leur différence, ni se poser comme une langue 'cultivée'; situation dans laquelle les membres de la communauté linguistique peuvent être tentés de parler d'autres langues plus 'éduquées'. (...) Ainsi le bilinguisme culturel allemand bloquera-t-il à la fois, et pendant longtemps, l'essor littéraire de la langue maternelle et celui des traductions. Car ce bilinguisme ne 
signifie pas une overture sur l'étranger, mais plutôt le fait d'être dominé par ce dernier (pp. 236-7).

O tradutor estrangeirizador para Schleiermacher segue o texto fonte o mais literalmente possível, para dar a seu público a sensação do estrangeiro. Essa estratégia pode gerar como conseqüência a sensação para o leitor de estar lendo não um texto estrangeirizador, mas um texto muito mal traduzido. Pym (1995) trata dessa possibilidade:

The difficulty with this method is that such literalism ('the translation follows the turns taken by the original'), as the highest and most difficult art, comes close to the easiest and most foolish, that of the naïve translationese. Translators risk going too far, betraying themselves and their language (p. 5).

Em consonância com o modelo binário de Schleiermacher, Venuti parte então desses conceitos para propor a sua estratégia de visibilidade do tradutor. Venuti adota os conceitos de tradução domesticadora, que naturaliza o discurso do autor deslocando-o em direção ao leitor, e estrangeirizadora, que dificulta a legibilidade do texto como estratégia de visibilidade, deslocando o leitor em direção ao autor.

A opção de Venuti é consoante àquela de Schleiermacher, ou seja, pela estrangeirizadora. Venuti chama a atenção para o caráter formador da prática tradutória e discute as estratégias vigentes no mercado:

Translation wields enormous power in constructing representations of foreign cultures. The selection of foreign texts and the development of translation strategies can establish peculiarly domestic canons for foreign literatures, canons that conform to domestic aesthetic values and therefore reveal exclusions and admissions, centers and peripheries that deviate from those current in the foreign language (1998, p. 67). 
E, por isso mesmo, a estratégia defendida por Venuti se daria por meio da subversão do cânone local e a conseqüente visibilidade do tradutor seria promovida, por exemplo, pela introdução de gêneros estrangeiros ou dando voz a grupos socialmente excluídos.

Em concordância com os mesmos ideais, Clark e Ivanic (1997) acreditam que:

Vast numbers of people as individuals but, more importantly, powerless social groups are excluded from contributing to the collective store of knowledge, cultural and ideological activity; from the production and projection of ideas that fundamentally shape society. Whole social and ethnic groups are largely voiceless, their experiences unrecorded and their right to contribute to the shaping of society virtually denied (p. 55).

Diferentemente de Schleiermacher, Venuti fundamenta sua opção estrangeirizadora em um posicionamento democrático contrário às práticas hegemônicas naturalizadoras recorrentes na cultura anglo-americana, e defende:

[t]his translation strategy is foreignizing in its resistance to values that prevail in contemporary Anglo-American culture - the canon of fluency in translation, the dominance of transparent discourse, the individualistic effect of authorial presence (p. 36).

Dessa maneira, Venuti estabelece, assim como Schleiermacher, mais um binarismo no longo histórico de opções excludentes na teoria da tradução, ou seja, a domesticação de valores, discursos e temática ou a sua estrangeirização. Pym chamou a atenção para essa repetição de modelos binários na teoria da tradução que desconsideram "o lugar do tradutor, como um terceiro elemento viável."3

A atitude de Venuti concernente ao papel social do tradutor remete ao posicionamento de Eagleton (1996) diante do pensamento 
pós-moderno, que "[a]pesar de toda a sua alardeada abertura para o Outro, o pós-modernismo pode se mostrar quase tão exclusivo e crítico quanto as ortodoxias a que ele se opõe" e acrescenta:

(...) por todo seu discurso sobre diferença, pluralidade, heterogeneidade, a teoria pós-moderna com freqüência trabalha com oposições binárias um tanto rígidas, em que os termos "diferença", "pluralidade" e congêneres aparecem bravamente alinhados num lado da cerca teórica na qualidade de positivos sem sombra de dúvida, ao passo que tudo que represente sua antítese (unidade, identidade, totalidade, universalidade) fica classificado de modo sinistro do outro ${ }^{4}$ (p. 34).

Faz-se necessário examinar a inserção da prática da escrita subversiva de Venuti no mercado. Eagleton observa que "o que funciona no nível da ideologia nem sempre funciona no nível de mercado." (p. 128). Clark e Ivanic, cujas idéias se assemelham à de Venuti, observam a reduzida penetração dessas práticas no mercado:

Although the political power of oppositional writers is limited, their work may be highly valued in certain sections of society that value their ideas and share their goals of challenging the status quo and offering different meanings and understanding" (p. 38).

É claro que fluência e inteligibilidade dos textos traduzidos são imposições do mercado, mas são também expectativa do leitor. Parece-me paradoxal Venuti pretender alçar o prestígio social tradutor dificultando o acesso do leitor ao texto, se a dificuldade implicará, na maioria das vezes, o desinteresse pelo material traduzido. O acesso ao texto estrangeirizador será limitado a uma reduzida elite intelectual, o que refuta a postura democrática e subversiva do autor. Segundo Bakhtin (1986), “[a] palavra é uma espécie de ponte lançada entre mim e os outros. Se ela se apóia sobre mim 
numa extremidade, na outra apóia-se sobre o meu interlocutor. A palavra é o território comum do locutor e do interlocutor." ${ }^{5}$ (p.113). No caso da tradução estrangeirizadora, a palavra não mais é território comum do leitor, é a subversão pela subversão, não há ponte porque uma das extremidades inexiste, uma vez que a opção de Schleiermacher e Venuti é excludente de leitura.

Schleiermacher afirma que

[t]he reader of the translation will become the equal of the better reader of the original only when he is able to first acquire an impression of the particular spirit of the author as well as that of the language of the work, and to develop a definite grasp of it by and by (pp. 157-8).

A citação acima aponta não apenas para a necessidade de um super leitor como também para a disparidade de propósitos de Schleiermacher e Venuti. Enquanto um exalta o autor e pretende lançar mão da estrangeirização para proporcionar ao seu leitor o prazer equivalente ao que sentiu expondo "the spirit of the language that was the author's and to see his own peculiar way of thinking and feeling." (p. 147), o outro parte exatamente da tentativa de desacreditar o autor para corroborar a mesma estratégia. Venuti lança mão do modelo binário proposto por Schleiermacher, mas toda a argumentação de Venuti só se sustenta se fundamentos, razões e metas existentes em Schleiermacher forem desconsiderados.

Venuti revê o belo, o verdadeiro e o natural quando os analisa mediante o relativismo histórico de Marx. A dialética prevê que

o absoluto e o relativo formam uma unidade indestrutível: a verdade absoluta possui seus próprios elementos relativos, ligados ao tempo, ao lugar e às circunstâncias. $\mathrm{E}$, por outro lado, a verdade relativa, enquanto verdade real, enquanto reflexo aproximativamente fiel da realidade, reveste-se de uma validez absoluta ${ }^{6}$ (LUKACS, p. 14). 
Assim, como analisou Venuti, sabe-se que o que é considerado um discurso coerente e aceitável nada mais é que uma contingência ideológica situada em um determinado momento histórico e que o objeto literário deve ser entendido dessa maneira.

Venuti defende estratégias de leitura e escrita subversivas, mas contesta a originalidade e a autoria. Parece-me contraditório que Venuti tenha a resposta para a questão da autoria na tradução, se ele também está inserido em um determinado contexto histórico limitador de visões de mundo. A pertinência da exposição de Venuti concernente ao papel determinante do contexto histórico nas manifestações discursivas está precisamente no fato de que não há como escapar de tais contingências.

Faz-se necessário uma análise detalhada que pretenda partir exatamente dessas contingências e analisar as propostas de intervenção consciente na prática da tradução por Schleiermacher e Venuti, considerando as divergências de enfoque e de finalidade e, partindo da busca pela autoria, verificar a aplicabilidade das propostas dos dois autores.

\section{Notas}

1. Anne Chevalier, L'ascèse de l'auteur. In: L'auteur. Presses Universitaires de Caen, 1996.

2. Tradução de André Lefevere.

3. Em inglês: (...) the place of the translator, as a viable third term.

4. Tradução de Elisabeth Barbosa. 
5. Tradução de Michel Lahud e Yara Frateschi Vieira.

6. Tradução de Leandro Konder.

\section{Bibliografia}

BAKHTIN, M. Marxismo e filosofia da linguagem. Tradução de Michel Lahud e Yara Frateschi Vieira. São Paulo: Hucitec, 1986.

BERMAN, A. L'épreuve de l'étranger: culture et traduction dans l'Allemagne romantique. Paris: Gallimard, 1984.

BRUNI, L. De interpretatione recta. Tradução de Rafafel Carmolinga. Inédito.

CÍCERO, M. T. De optimo genere oratoribus. Tradução de Mauri Furlan. Inédito.

CLARK, R., IVANIC, R. The politics of writing. Londres e Nova York: Routledge, 1997.

EAGLETON, T. As ilusões do pós-modernismo. Tradução de Elisabeth Barbosa. Rio de Janeiro: Jorge Zahar, 1998.

LUKÁCS, G. Ensaios sobre literatura. Tradução de Leandro Konder. Rio de Janeiro: Civilização Brasileira, 1968.

MOUNIN, G. Teoria e storia della traduzione. Tradução de Stefania Morganti. Turim: Piccola Biblioteca Einaudi, 1965. 
PYM, A. "Schleiermacher and the problem of Blendlinge". In: Translation and literature 4/1 (5-30), 1995. Também disponível no: http://www.fut.es/ apym/ on-line/blendlinge.pdf

SCHLEIERMACHER, F. "On the differents methods of translating”. Tradução de Andre Lefevere. In: LEFEVERE, A et al. Translation/ History/ Culture: a sourcebook. Londres e Nova York: Routledge,1992.

VENUTI, L. Rethinking translation: discourse, subjectivity, ideology. Londres e Nova York, 1992.

. The translator's invisibility: a history of translation. Londres e Nova York: Routledge, 1995.

. The scandals of translation: towards an ethics of difference. Londres e Nova York: Routledge, 1998. 